\title{
COPING STYLES, DYSFUNCTIONAL SCHEMES AND PSYCHOPATHOLOGICAL SYMPTOMS RELATED TO EMOTIONAL DEPENDENCE ON THE AGGRESSOR PARTNER
}

\author{
Janire Momeñe ${ }^{1,2}$, Ana Estévez1 , Ana María Pérez-García², \\ Leticia Olave $^{3}$ and Itziar Iruarrizaga ${ }^{3}$ \\ ${ }^{1}$ University of Deusto; ${ }^{2}$ National Distance Learning University (UNED); \\ Complutense University of Madrid (Spain)
}

\begin{abstract}
Coping styles, dysfunctional schemes and psychopathological symptoms could be factors of vulnerability that increase the probability that a person develops emotional dependence on an aggressive partner. Delimiting the risk factors is fundamental for its prevention and treatment. Consequently, the main objectives of the present study were to analyze the relationship between the above-mentioned factors, as well as the mediating role of the first three in the relationship between emotional dependence and received violence. The sample was made up of 657 women from the clinical and general population, with ages ranging from 18 to 66 years of age $(M=23.38, S D=8.24)$. The results reflected the predominance of inadequate coping styles, such as desiderative thinking, social isolation and self-critical, psychopathological symptoms of depression, anxiety, interpersonal sensibility, obsession-compulsion and paranoid ideation, as well as abandonment and subjugation schemes. These factors also explained part of the relationship between emotional dependence and staying in violent relationships.

KEY WORDS: Coping styles, schemes, psychopathological symptoms, emotional dependence, violence received.

\section{Resumen}

Los estilos de afrontamiento, los esquemas disfuncionales y la sintomatología psicopatológica podrían resultar factores de vulnerabilidad que incrementan la probabilidad de que una persona desarrolle dependencia emocional hacia la pareja agresora. Delimitar los factores de riesgo es fundamental para su prevención y tratamiento. Consecuentemente, el presente estudio tuvo como objetivos principales analizar la relación entre los factores señalados, así como el papel mediador de los tres primeros en la relación entre la dependencia emocional y la violencia recibida. La muestra estuvo conformada por 657 mujeres procedentes de población clínica y general, con edades que oscilaron entre los 18 y 66 años $(M=23,38 ; D T=8,24)$. Los resultados reflejaron la predominancia del empleo de estilos de afrontamiento inadecuados, tales como
\end{abstract}

Study financed by the Foundation Jesús de Gangoiti Barrera.

Correspondence: Ana Estévez, Avda. de las Facultades, 24, 48007 Bilbao (Spain). E-mail: aestevez@deusto.es 
pensamiento desiderativo, aislamiento social y autocrítica, síntomas psicopatológicos de depresión, ansiedad, sensibilidad interpersonal, obsesióncompulsión e ideación paranoide, así como esquemas de abandono y subyugación. Asimismo, estos factores explicaron una parte de la relación entre la dependencia emocional y la permanencia en relaciones violentas.

PALABRAS CLAVE: Estilos de afrontamiento, esquemas, síntomas psicopatológicos, dependencia emocional, violencia recibida.

\section{Introduction}

Gender violence is one of the great challenges facing society today due to its high incidence and relevance (Fernández-González, Calvete, \& Orue, 2017). It is also an important social and public health problem due to the negative physical and psychological consequences it has on the victim (Crane \& Easton, 2017; Crombie, Hooker, \& Reisenhofer, 2017; Ruiz-Pérez, Pastor-Moreno, Escribà-Agüir, \& Maroto-Navarro, 2018). Partner violence increases in frequency and intensity over time as the relationship progresses (Del Castillo, Hernández, Romero, \& Iglesias, 2015). It can be expressed in three different ways; psychological, physical and sexual (Echeburúa, 2018; Lee \& Lee, 2018; Sloand et al., 2017), the former being the most prevalent (Mohammad-Alizadeh-Charandabi, Bahrami-Vazir, Kamalifard, \& Mirghafourvand, 2016).

Several studies have pointed out that emotional dependence on the aggressor partner would favor the permanence of the victim in the relationship (Momeñe \& Estévez, 2018; Urbiola et al., 2019), since it would make it difficult for the partner to break up (Urbiola, Estévez, \& Iraurgi, 2014), as well as it could favor the return to the relationship once it has ended (Miramontes \& Mañas, 2018). It is common for victims of intimate partner violence to report remaining in love with their partners despite the severity of the violence received (Castelló, 2005). Previous studies have shown how women who suffer intimate partner violence report higher rates of emotional dependence compared to those who do not (Huerta et al., 2016; Moral, García, Cuetos, \& Sirvent, 2017).

Emotional dependence towards the partner can be defined as a pattern of unsatisfied affective needs that try to be covered in a maladaptive way through interpersonal relationships (Urbiola, Estévez, Iruarrizaga, \& Jauregui, 2017). People with emotional dependence manifest an intense terror of abandonment by their partner, leading them to exercise controlling, possessive and restrictive behaviors in order to limit their partner's autonomy (Echeburúa \& Fernández-Montalvo, 2010; Petruccelli et al., 2014), obtain their attention, affection and constant closeness that are never enough (Izquierdo \& Gómez-Acosta, 2013; Markez, 2015). In this way, they deploy a wide repertoire of retentive strategies in order to ensure the permanence of the partner in the relationship (Riso, 2014). The partner occupies a priority place (Castelló, 2019), they consider it the center of their existence, idealize it and assume submissive behaviors (Castelló, 2012), passively adapt to it, show lack of initiative and inability to realize the adverse effects of the relationship (Sirvent \& Moral, 2018), thus establishing pathological and unbalanced relationships (Castelló, 2005). They manifest feelings of emotional emptiness, loss 
of identity and being incomplete without the partner (Moral, Sirvent, Ovejero, \& Cuetos, 2018; Urbiola et al., 2014). Moreover, despite suffering in the relationship the breakup would cause further suffering, being trapped in a vicious cycle (Skvortsova \& Shumskiy, 2014).

In this regard, it has been mentioned that childhood experiences or events influence the establishment of couple relationships and social functioning in adulthood (Oliva, 2011). In this line, previous studies have found that women who remain in violent relationships report having lived traumatic experiences in childhood related to high parental trauma (Loubat, Ponce, \& Salas, 2007). Likewise, the origin of emotional dependence is located in early affective deficiencies during childhood (Castelló, 2005). In the presence of a traumatic event and in order to overcome the emotional damage caused, coping strategies are implemented. These coping styles used to deal with stressful or adverse situations can be both positive and negative and are relatively stable in each person over time (Echeburúa \& Amor, 2019). No scientific articles are found that analyze coping styles in people with emotional dependence. However, it has been mentioned that women who suffer intimate partner violence show negative avoidant coping strategies (Moral de la Rubia, López, Díaz, \& Cienfuegos, 2011).

For their part, early dysfunctional schemas can be understood as stable internalized patterns that have been acquired through early affective experiences or negative interactions carried out with representative figures in childhood (Estévez, 2013). They influence the way we feel, think, act and relate to others in adulthood (Young, Klosko, \& Weishaar, 2013). Higher rates of early dysfunctional schemas have been mentioned in women victims of intimate partner violence compared to those who do not suffer it (Calvete, Estévez, \& Corral, 2007), as well as among people who present emotional dependence (Urbiola \& Estévez, 2015; Lemos, Jaller, González, Díaz, \& De la Ossa, 2012).

Finally, it should be noted that remaining in violent intimate partner relationships has been associated with multiple psychopathological symptoms, with low self-esteem (Van Ouytsel, Ponnet, \& Walrave, 2017), depression (Lara, Aranda, Zapata, Bretones, \& Alarcón, 2019), suicidal ideation (Llosa \& Canetti, 2019), and anxiety (Coll-Vinent et al., 2019) being noteworthy. For its part, emotional dependence is also linked to psychopathological symptoms such as obsession-compulsion, depression, anxiety, hostility, paranoid ideation, psychoticism (Santamaría et al., 2015), low self-esteem (Urbiola et al., 2017) and low resilience (Momeñe \& Estévez, 2019), emotional oscillations (Skvortsova \& Shumskiy, 2014) and self-injurious behaviors (Bornstein, 2012).

Thus, there is scientific evidence of the relationship between emotional dependence, permanence in violent relationships, negative coping styles, dysfunctional schemas and psychopathological symptomatology. However, to date there have been no studies examining the impact of the latter three on the association between emotional dependence and intimate partner violence received. That is, although the association between emotional dependence and staying in violent intimate partner relationships has been demonstrated, it is necessary to understand the mechanisms underlying this association. Therefore, the first underlying hypothesis of the present study would be that women who are 
emotionally dependent towards their partners and women who have suffered violence employ negative coping styles, show dysfunctional schemas and present psychopathological symptoms. The second underlying hypothesis is that negative coping styles, dysfunctional schemas and psychopathological symptoms would act as explanatory mechanisms for emotional dependence towards the aggressor partner. Thus, these hypotheses correspond to the objectives of the study, which would be, first, to analyze the relationship between the study variables. Secondly, once these relationships have been verified, we will evaluate whether coping styles, dysfunctional schemas and psychopathological symptoms act as mediators in the relationship between emotional dependence and violence.

\section{Method}

\section{Participants}

The sample consisted of 657 women aged 18 to 66 years $(M=23.38, S D=$ 8.24). All of them had been in a couple relationship in the past or were in a couple relationship at the time of participating in the study. On the one hand, they came from the clinical population $(n=44)$, that is, women who had suffered intimate partner violence and who at the time of the study were in centers for the treatment of this problem. On the other hand, the sample came from the general population ( $n=613)$, university women and women recruited online through social networks. Likewise, women of Spanish nationality predominated ( $n=621)$. Regarding sexual orientation, 544 defined themselves as heterosexual, 28 homosexual, 83 bisexual and 2 chose not to answer. Regarding the level of education, 1 had no education, 2 had primary education, 15 had secondary education, 20 had vocational training, 618 had university education and 1 did not answer.

\section{Instruments}

a) Revised Conflicts Tactics Scale-2 (CTS-2; Straus, Hamby, Boney-McCoy, \& Sugarman, 1996), Spanish-adapted version of Graña, Andreu, Peña and Rodríguez-Biezma (2013). It evaluates both the violence exercised and received, as well as the use of negotiation as a method of conflict resolution in couple relationships. The scale is composed of 78 items, of which 39 refer to actions performed by the person answering the questionnaire and the other 39 items to actions performed by the partner. It contains five scales: negotiation, physical aggression, psychological abuse, sexual coercion and injuries. The negotiation scale is divided into two subscales, cognitive and emotional, and the rest of the scales are also divided into two subscales, minor and severe. Negotiation refers to the actions taken to end a disagreement through discussion and reasoning. The items of the cognitive scale assess such discussions. The emotional scale, on the other hand, evaluates the extent to which the couple communicates positive affective feelings to each other, seeking expressions of affection and respect within the couple. The physical 
aggression scale refers to physical violence. The psychological abuse scale includes acts of verbal violence and acts of nonverbal violence. Sexual coercion is defined as behavior aimed at forcing a partner to engage in unwanted sexual activity. Finally, the injury scale measures the physical harm inflicted, i.e., broken bones, need for medical assistance or continued pain. The scale has eight response alternatives indicating the number of times a violent act has occurred in the last 12 months $(0=$ "Never", $1=$ "Once", 2= "Twice", $3=$ "Three to five times", 4= "Six to ten times" , 5= "Eleven to twenty times", $6=$ "More than twenty times" and $7=$ "Not in the past year, but previously"). It also presents four indicators: Prevalence (it is dichotomous (0-1), indicating whether the acts have occurred or not); Chronicity (it refers to the number of times an act of a scale has occurred); Lifetime prevalence (it takes as a time reference the entire life of the person completing the questionnaire); Annual frequency (it weighs the items of each scale by their frequency of occurrence). In the present study, the 39 items referring to intimate partner violence will be used. The higher the score, the greater the violence received. The total scale of violence received has shown good psychometric properties in the Spanish adult population, obtaining a Cronbach's alpha coefficient of .83. In this way, the victimization subscales have also obtained good internal consistency, negotiation $(\alpha=.75)$, physical aggression $(\alpha=.80)$, psychological abuse $(\alpha=$ .73), sexual coercion $(\alpha=.63$ ) and injuries ( $\alpha=.69)$ (Graña et al., 2013). In the present study, Cronbach's alpha coefficient for the total victimization subscale was .91 (negotiation $\alpha=.85$, physical aggression $\alpha=.90$, psychological abuse $\alpha=.87$, sexual coercion $\alpha=.87$ and injuries $\alpha=.88$ ).

b) Emotional Dependence Questionnaire ("Cuestionario de dependencia emocional", CDE; Lemos \& Londoño, 2006). It is composed of 23 items grouped into six factors: separation anxiety, emotional expressions of fear that are produced by the possibility of dissolution of the relationship; affective expression, the need to have constant expressions of affection from their partner that reaffirm the love they feel for each other and soothe the feeling of insecurity; modification of plans, the change of activities, plans and behaviors due to implicit or explicit desires to satisfy the partner or the simple possibility of sharing more time with them; fear of loneliness, fear of not having a partner relationship, or of feeling that he/she is not loved; limit expression, performing actions or manifesting impulsive expressions of selfaggression in the face of a possible breakup of a relationship, since this can be something catastrophic due to his/her confrontation with loneliness and the loss of meaning in life; attention seeking, actively seeking attention from the partner to ensure his/her permanence in the relationship and to try to be the center of attention in his/her life. The format is Likert-type with six response alternatives ranging from 1 ("Completely untrue of me") to 6 ("Describes me perfectly"). The higher the score, the greater the emotional dependence on the partner. The questionnaire presents good internal consistency, obtaining a Cronbach's alpha coefficient of .93 (Lemos \& Londoño, 2006). In the present study, Cronbach's alpha coefficient for the total scale was .94. 
c) Coping Strategies Inventory (CSI; Tobin, Holroyd, Reynolds, \& Wigal, 1989), Spanish-adapted version of Jáuregui, Herrero-Fernández, and Estévez (2016). It measures coping strategies used by means of 41 items. It presents a hierarchical structure composed of eight primary, four secondary and two tertiary scales. The eight primary scales assess eight coping strategies: problem solving, strategies aimed at eliminating stress by modifying the stressful situation; cognitive restructuring, strategies aimed at modifying the meaning of the stressful situation; social support, strategies aimed at seeking emotional support; express emotions, strategies that consist of releasing emotions that arise in stressful situations; problem avoidance, strategies aimed at denying or avoiding thoughts and actions linked to the stressful situation; Wishful thinking, cognitive strategies that show the wish that reality were not stressful; Social withdrawal, strategies that consist of distancing oneself from significant people who are associated with the emotional reaction during the stressful situation; self-criticism, strategies aimed at self-blame and self-criticism for an inadequate management or occurrence of the stressful situation. These eight primary scales are grouped into four secondary scales: problem-focused adequate coping, involves problem-focused adaptive coping (problem solving and cognitive restructuring); emotion-focused adequate coping, consists of adaptive coping focused on managing emotions (social support and express emotions); inadequate problem-focused coping consists of maladaptive problem-focused coping through avoidance or fantasy about past, present or future alternative realities (problem avoidance and wishful thinking); inadequate emotion-focused coping involves maladaptive emotion-focused coping involving isolation, self-criticism and self-blame (social withdrawal and self-criticism). Similarly, the four secondary scales are grouped into two tertiary scales: adequate coping consists of active and adaptive efforts to compensate for the stressful situation (problem solving, cognitive restructuring, social support and express emotions); inadequate coping consists of passive and maladaptive coping with the stressful situation (problem avoidance, wishful thinking, social withdrawal and self-criticism). The format is Likert-type with five response alternatives ranging from 0 ("Not at all") to 4 ("Completely"). The higher the score, the greater the coping style employed. It presents good psychometric properties obtaining a Cronbach's alpha coefficient between .75 and .89 (Jáuregui et al., 2016). In the present study Cronbach's alpha coefficient for the total scale was .82 (problem solving $\alpha=.83$, cognitive restructuring $\alpha=.81$, social support $\alpha=.87$, express emotions $\alpha=.79$, problem avoidance $\alpha=.69$, wishful thinking $\alpha=.84$, social withdrawal $\alpha=.76$, selfcriticism $\alpha=.88$ ).

d) Schema Questionnaire-Short Form (SQ-SF; Young \& Brown, 1994), Spanishadapted version of Calvete, Estévez, López de Arroyabe, and Ruiz (2005). It evaluates 18 early dysfunctional schemas divided into five domains. In the present study, eight dysfunctional schemas will be used. Disconnection and rejection domain: abandonment, consists of the belief that significant others will not provide the emotional support or protection you need because sooner 
or later they will leave you for someone better; abuse/distrust, involves the belief that others will deliberately or intentionally hurt, humiliate, deceive and lie to you; imperfection/blame, refers to the belief that you are flawed, defective, unloved, unworthy and inferior. They show a generalized belief that others will not like them if they know their true self; Impaired autonomy domain: attachment/enmeshment, consists of an excessive search for intimacy and emotional involvement with other people, and show beliefs that they cannot be happy without the constant support of those people; dependencelincompetence, refers to the belief of being unable to cope or carry out daily responsibilities or tasks without the help of other people; Otheroriented domain: self-sacrifice, refers to the exaggerated and willful satisfaction of others' needs at the expense of gratification of one's own needs; subjugation, involves excessive surrender to the control of others and relinquishment of one's rights because the person feels coerced by others in order to avoid angry reactions or possible abandonment. Dominance of excessive vigilance and inhibition: unattainable standards, involves the belief that one must achieve great accomplishments or act in a way that is considered perfect in order to avoid being criticized or rejected. The questionnaire is made up of 75 items in Likert-type format with six response alternatives ranging from 1 ("Totally false") to 6 ("It describes me perfectly"). The higher the score, the higher the early dysfunctional schema. The Spanish version of the SQ-SF has shown good reliability, obtaining a Cronbach's alpha coefficient the total scale of .97 (Iruarrizaga et al., 2019). In the present study the subscales obtained an adequate Cronbach's alpha coefficient (abandonment $\alpha=.89$, abuse/distrust $\alpha=.88$, imperfection/blame $\alpha=.83$, attachment/enmeshment $\alpha=.68$, dependence/incompetence $\alpha=.75$, selfsacrifice $\alpha=.84$, subjugation $\alpha=.82$, unattainable standards $\alpha=.80$ ).

e) Symptom Assessment-45 Questionnaire (SA-45; Davison et al., 1997), Spanish version of Sandín, Valiente, Chorot, Santed, and Lostao (2008). This is an abbreviated version of the SCL-90-R made up of 45 items. It evaluates psychopathological symptoms through 9 scales composed of 5 items each: hostility, somatization, depression, obsession-compulsion, anxiety, interpersonal sensitivity, phobic anxiety, paranoid ideation and psychoticism. The format is Likert-type with five response alternatives ranging from 0 ("Not at all ") to 4 ("Very much or extremely"). The higher the score, the greater the psychopathological symptom. The psychometric properties of the total questionnaire were good, obtaining a Cronbach's alpha coefficient of .96. As for the 9 scales that make up the questionnaire also obtained good internal consistency; hostility, depression, and interpersonal sensitivity $(\alpha=.85)$, somatization ( $\alpha=.79)$, anxiety $(\alpha=.82)$, psychoticism ( $\alpha=.57)$, paranoid ideation $(\alpha=.74)$, obsession-compulsion and phobic anxiety $(\alpha=.81)$ (Alvarado, Sandín, Valdez-Medina, González-Arratia, \& Rivera, 2012). In the present study, Cronbach's alpha coefficient for the total scale was .95 (depression $\alpha=.87$, hostility $\alpha=.79$, interpersonal sensitivity $\alpha=.86$, 
somatization $\alpha=.81$, anxiety $\alpha=.84$, psychoticism $\alpha=.64$, obsessioncompulsion $\alpha=.77$, phobic anxiety $\alpha=.80$, paranoid ideation $\alpha=.75$ ).

\section{Procedure}

Consent was received from the Research Ethics Committee of the University of Deusto with reference EKT-30/18-19 and we proceeded to contact the centers that dealt with the problem of intimate partner violence.

Thus, participation in the study was promoted in two ways. The first was in person, administering the battery of questionnaires that made up the study in group sessions through independent and anonymous booklets with instructions in pencil and paper format to women who stayed in centers aimed at dealing with the problem of intimate partner violence $(n=26)$, as well as to university students in the community of Madrid $(n=560)$. The second was via the Internet through different social networks (Facebook and Twitter), where a link was included for online access to the computerized version of the questionnaires $(n=97)$. In this second route, the women who reported having been victims of intimate partner violence were in the clinical population group $(n=18)$ and the rest in the general population group $(n=53)$. It should be noted that both participation procedures required the signature of an informed consent form.

In relation to in-person data collection, before starting to fill in the questionnaires individually, the voluntary nature of participation and the possibility of leaving the study at any time, anonymity and confidentiality of the data obtained were emphasized, and the characteristics of the research were explained: approximate duration, the two inclusion criteria (being over 18 years of age and having a partner relationship at the time of participating in the study or having had one in the past), the importance of sincerity when answering the questionnaires and the absence of good or bad answers, all of which were good and appropriate. Likewise, the main objective of the study was pointed out: to deepen the knowledge of couple relationships. Sociodemographic data were requested and then they could proceed to fill in the questionnaires measuring the selected variables. The response to the questionnaires measuring emotional dependence and partner violence had to be based on an established relationship that they considered problematic, complicated or stormy. If they did not consider that they had maintained this type of relationship, they had to base their answers on the last relationship they had maintained. Once the task was completed, the participants handed it in and once collected, the data provided were entered into the database. They were also provided with a contact e-mail address to resolve possible doubts or to request the results of the study if they were interested.

Regarding online data collection, a Google Drive account was created where the computerized version of the questionnaires was included. Subsequently, social networks were used to promote participation in the study where a link was included to access Google Drive and, therefore, to participate in the research on an individual basis. In this regard, the sample was collected by non-probabilistic sampling, using the snowball methodology. The beginning of the questionnaire completion was preceded by a section that included the objective of the study and 
a brief explanation of the research characteristics mentioned above. Participants were then able to begin answering the questionnaires and the results were stored in a database. It was only possible to participate once.

Data analysis

First, the bivariate relationships between emotional dependence, violence received, coping styles, early dysfunctional schemas and psychopathological symptomatology were analyzed by means of Pearson's $r$. Second, third and fourth, three-step linear regression analyses (Baron \& Kenny, 1986) were conducted to test a mediation model that included coping styles, dysfunctional schemas and psychopathological symptoms as hypothesized mediators in the relationship between emotional dependence and intimate partner violence received. In the first step, emotional dependence must be statistically significantly associated with violence. In the second step, emotional dependence should be significantly associated with the mediating variables. In the third and final step, the relationship between emotional dependence and violence received should be significantly reduced by adding the mediating variables to the model. The effect of mediation was evaluated through the bootstrapping procedure that provides $95 \%$ confidence intervals. Statistical analyses were carried out using IBM SPSS Statistics v. 22.0.

\section{Results}

First, the relationships between emotional dependence, violence received, coping styles, early dysfunctional schemas and psychopathological symptomatology were analyzed (Table 1). Correlation analyses highlighted the positive relationship between emotional dependence and violence received with inadequate coping styles, predominantly those centered on emotion, such as wishful thinking, social withdrawal and self-criticism. With respect to early dysfunctional schemas, positive relationships predominated with the abandonment and subjugation schema. Likewise, they showed positive relationships with psychopathological symptoms, highlighting depression, interpersonal sensitivity, anxiety, obsession-compulsion and paranoid ideation.

Second, the mediating role of negative coping styles in the relationship between emotional dependence and intimate partner violence received was tested. The statistically significant results are shown below (Table 2). The results obtained reflected how emotional dependence was significantly associated with increased violence received and the coping styles of cognitive restructuring, express emotions, wishful thinking, social withdrawal and self-criticism explained part of this association. Thus, the coping styles mentioned explained $18.18 \%$ of the variance in the relationship between emotional dependence and physical violence, $18.75 \%$ of the variance in the relationship between emotional dependence and psychological violence, $12.5 \%$ of the variance in the relationship between emotional dependence and sexual violence, and $33.33 \%$ of the variance in the relationship between emotional dependence and injury. 
Table 1

Descriptive statistics of emotional dependence and types of violence and correlations between study variables

\begin{tabular}{|c|c|c|c|c|c|}
\hline Variables & 1 & 2 & 3 & 4 & 5 \\
\hline$M$ & 47.01 & 3.67 & 8.51 & 2.53 & 1.35 \\
\hline$S D$ & $(19.44)$ & $(11.44)$ & $(11.03)$ & $(6.77)$ & $(5.01)$ \\
\hline \multicolumn{6}{|l|}{ Coping styles } \\
\hline Cognitive restructuring & $-.08^{*}$ & -.07 & -.05 & -.01 & -.06 \\
\hline Social support & $-.11 * *$ & $-.13^{* *}$ & $-.11 * *$ & $-.08^{*}$ & $-.11 * \star$ \\
\hline Express emotions & $-.11 * \star$ & .02 & .07 & .00 & .02 \\
\hline $\begin{array}{l}\text { Inadequate problem-focused } \\
\text { management }\end{array}$ & $.23 * *$ & $.09 *$ & $.10 * \star$ & $.09 *$ & $.12 * *$ \\
\hline Wishful thinking & $.30 * *$ & $.09 *$ & $.14 * *$ & $10 * \star$ & $.12^{* *}$ \\
\hline $\begin{array}{l}\text { Inadequate emotion-focused } \\
\text { management }\end{array}$ & $.38 * \star$ & $.22 * *$ & $.24 * \star$ & $20 * *$ & $.22 * *$ \\
\hline Social withdrawal & $.29 * *$ & $.22 * \star$ & $.23^{* *}$ & $20 * *$ & $.24 * *$ \\
\hline Self-criticism & $.35 * \star$ & $.15^{\star}$ & $.18^{* \star}$ & $14^{\star *}$ & $.15^{* *}$ \\
\hline \multicolumn{6}{|l|}{ Psychopathological symptoms } \\
\hline Depression & $.47 * \star$ & $.15^{\star *}$ & $.24 * *$ & $.18^{* *}$ & $.18^{* \star}$ \\
\hline Hostility & $.35 * \star$ & $.13^{* \star}$ & $.20 * \star$ & $.14^{\star \star}$ & $.14^{* *}$ \\
\hline Interpersonal sensitivity & $.46^{\star \star}$ & $.08 *$ & $.17 * \star$ & $.13^{\star \star}$ & $.10 * \star$ \\
\hline Somatization & $.29 * *$ & $.14^{* \star}$ & $.21 * *$ & $.16^{* *}$ & $.19^{* *}$ \\
\hline Anxiety & $.45^{\star \star}$ & $.14^{\star \star}$ & $.26^{\star *}$ & $.19 * *$ & $.17^{* *}$ \\
\hline Psychoticism & $.39 * *$ & $.12^{* \star}$ & $.17^{* *}$ & $.15^{\star \star}$ & $.16^{* *}$ \\
\hline Obsession-compulsion & $.45^{* *}$ & .07 & $.14^{* \star}$ & $11^{* *}$ & $.11^{* *}$ \\
\hline Phobic anxiety & $.34 * \star$ & $.19 * *$ & $.18^{\star *}$ & $22 * \star$ & $21 * *$ \\
\hline Paranoid ideation & $.51 * *$ & $.11 * \star$ & $.19^{* *}$ & $.17 * \star$ & $.13^{* *}$ \\
\hline \multicolumn{6}{|l|}{ Early dysfunctional schemas } \\
\hline Abandonment & $.64 * \star$ & .07 & $.14 * \star$ & $.12 * *$ & $.09 *$ \\
\hline Abuse/distrust & $.50 * *$ & $.17^{* *}$ & $.25^{* *}$ & $.22^{* *}$ & $20 * *$ \\
\hline Imperfection/blame & $.40 * *$ & $.10^{*}$ & $.14^{\star *}$ & $.11 * \star$ & $.13 * \star$ \\
\hline dependence/ incompetence & $.47^{\star \star}$ & $.20 * \star$ & $.26^{\star *}$ & $.20 * \star$ & $.20 * \star$ \\
\hline Attachment & $40 * \star$ & $.12 * \star$ & $.18^{* *}$ & $.15^{* *}$ & $.13^{* *}$ \\
\hline Subjugation & $.57 * *$ & $.18^{* *}$ & $.27 * \star$ & $20^{* *}$ & $.19^{* *}$ \\
\hline Self-sacrifice & $.26^{\star \star}$ & .04 & $.09 *$ & $.10^{\star \star}$ & .06 \\
\hline Unattainable standards & $.30 * \star$ & .04 & $.15^{\star *}$ & $.13^{* *}$ & .07 \\
\hline
\end{tabular}

Notes: $1=$ emotional dependence; $2=$ physical aggression; $3=$ psychological abuse; $4=$ sexual coercion; $5=$ injuries. ${ }^{*} p<.05,{ }^{*} p<.001$. 
Table 2

Mediation model including emotional dependence $(X)$, coping styles $(M)$ and intimate partner violence $(\mathrm{Y})$

\begin{tabular}{|c|c|c|c|c|}
\hline Variables & B & $\beta$ & $t$ & $95 \% \mathrm{Cl}$ \\
\hline \multicolumn{5}{|l|}{ Step 1: Emotional dependence } \\
\hline Physical aggression received & .11 & .20 & $5.14^{* *}$ & {$[.05-.18]$} \\
\hline Psychological violence received & .16 & .28 & 7.42 ** & {$[.11-.21]$} \\
\hline Sexual coercion received & .08 & .23 & $5.94^{* *}$ & {$[.04-.11]$} \\
\hline Injuries received & .06 & .23 & $5.91 * *$ & {$[.03-.09]$} \\
\hline \multicolumn{5}{|l|}{ Step 2: Emotional dependence } \\
\hline Cognitive restructuring & -.02 & -.08 & $-2.06^{*}$ & {$[-.04-.00]$} \\
\hline Express emotions & .03 & .11 & $2.72 *$ & {$[.01-.04]$} \\
\hline Wishful thinking & .08 & .30 & $8.08^{* *}$ & {$[.06-.10]$} \\
\hline Social withdrawal & .06 & .29 & $7.67 * *$ & {$[.05-.08]$} \\
\hline Self-criticism & .10 & .35 & $9.61 * *$ & {$[.07-.12]$} \\
\hline \multicolumn{5}{|c|}{ Step 3: Emotional dependence and coping styles } \\
\hline Physical aggression received & .09 & .16 & $3.83^{* *}$ & {$[.03-.16]$} \\
\hline Psychological violence received & .13 & .24 & $5.63 * *$ & {$[.08-.18]$} \\
\hline Sexual coercion received & .07 & .19 & $4.52 * *$ & {$[.02-.11]$} \\
\hline Injuries received & .04 & .19 & $4.48 * *$ & {$[.01-.08]$} \\
\hline
\end{tabular}

Note: ${ }^{*} p<.05,{ }^{* *} p<.001$.

Table 3

Mediation model including emotional dependence $(X)$, early dysfunctional schemas $(M)$ and intimate partner violence $(Y)$

\begin{tabular}{|c|c|c|c|c|}
\hline Variables & $B$ & $\beta$ & $t$ & $95 \% \mathrm{Cl}$ \\
\hline \multicolumn{5}{|l|}{ Step 1: Emotional dependence } \\
\hline Physical aggression received & .11 & .20 & $5.14 * *$ & {$[.05 \mathrm{a} .18$} \\
\hline Psychological violence received & .16 & .28 & $7.42^{* *}$ & {$[.11$ a .21} \\
\hline Sexual coercion received & .08 & .23 & $5.94 * \star$ & {$[.04 \mathrm{a} .11$} \\
\hline Injuries received & .06 & .23 & $5.91 * \star$ & {$[.03$ a .09} \\
\hline \multicolumn{5}{|l|}{ Step 2: Emotional dependence } \\
\hline Abandonment & .20 & .64 & $21.27^{\star \star *}$ & {$[.18 \mathrm{a} .22$} \\
\hline Abuse/distrust & .14 & .50 & $14.63^{* *}$ & {$[.12 \mathrm{a} .17$} \\
\hline Dependence/incompetence & .09 & .47 & 13.70 ** & {$[.07 \mathrm{a} .11$} \\
\hline Attachment & .08 & .40 & $11.02 * *$ & {$[.06 \mathrm{a} .10$} \\
\hline Subjugation & .14 & .57 & $17.59 * *$ & {$[.11 \mathrm{a} .16$} \\
\hline Unattainable standards & .09 & .30 & $8.14 * *$ & {$[.07 \mathrm{a} .11$} \\
\hline Imperfection/blame & .09 & .40 & $10.96 * *$ & $.07 \mathrm{a} .111$ \\
\hline Self-sacrifice & .08 & .26 & $6.92 * *$ & {$[.06 \mathrm{a} .11$} \\
\hline \multicolumn{5}{|c|}{ Step 3: Emotional dependency and dysfunctional schemas } \\
\hline Physical aggression received & .09 & .17 & $3.08^{* \star}$ & {$[.04 \mathrm{a} .16$} \\
\hline Psychological violence received & .11 & .20 & $3.76^{* *}$ & {$[.05 \mathrm{a} .17$} \\
\hline Sexual coercion received & .05 & .16 & $2.99 * *$ & {$[.02$ a .10} \\
\hline Injuries received & .04 & .18 & $3.44^{* *}$ & {$[.02 \mathrm{a} .08$} \\
\hline
\end{tabular}

Note: ${ }^{*} p<.05,{ }^{*} p<.001$. 
Third, the mediating role of early dysfunctional schemas in the relationship between emotional dependence and intimate partner violence received was tested (Table 3). As can be seen, emotional dependence was statistically significantly associated with intimate partner violence, and all dysfunctional schemas explained part of this relationship. Thus, dysfunctional schemas explained $18.18 \%$ of the variance in the relationship between emotional dependence and physical violence, $31.25 \%$ of the variance in the relationship between emotional dependence and psychological violence, $37.50 \%$ of the variance in the relationship between emotional dependence and sexual violence, and $33.33 \%$ of the variance in the relationship between emotional dependence and injuries.

Fourth, the mediating role of psychopathological symptomatology in the relationship between emotional dependence and intimate partner violence received was tested (Table 4). The results obtained showed that emotional dependence was statistically significantly associated with violence received, and psychopathological symptoms explained part of this association. They explained $9.09 \%$ of the variance in the relationship between emotional dependence and physical violence, $25 \%$ of the variance in the relationship between emotional dependence and psychological and sexual violence, and $16.67 \%$ of the variance in the relationship between emotional dependence and injuries.

Table 4

Mediation model including emotional dependence $(X)$, psychopathological symptoms (M) and intimate partner violence $(Y)$

\begin{tabular}{|c|c|c|c|c|}
\hline Variables & $B$ & $\beta$ & $t$ & $95 \% \mathrm{Cl}$ \\
\hline \multicolumn{5}{|l|}{ Step 1: Emotional dependence } \\
\hline Physical aggression received & .11 & .20 & $5.14^{\star \star}$ & {$[.05-.18]$} \\
\hline Psychological violence received & .16 & .28 & $7.42 * \star$ & {$[.11-.21]$} \\
\hline Sexual coercion received & .08 & .23 & $5.94^{\star *}$ & {$[.04-.11]$} \\
\hline Injuries received & .06 & .23 & $5.91 * *$ & {$[.03-.09]$} \\
\hline \multicolumn{5}{|l|}{ Step 2: Emotional dependence } \\
\hline Depression & .12 & .47 & $13.38^{\star *}$ & {$[.10-.14]$} \\
\hline Hostility & .06 & .35 & $9.65 * \star$ & {$[.05-.08]$} \\
\hline Interpersonal sensitivity & .11 & .46 & $13.02 * *$ & {$[.10-.13]$} \\
\hline Somatization & .07 & .29 & $7.74 * *$ & {$[.05-.09]$} \\
\hline Anxiety & .11 & .45 & $12.66 * *$ & {$[.09-.13]$} \\
\hline Psychoticism & .05 & .39 & $10.64 * *$ & {$[.04-.06]$} \\
\hline Obsession-compulsion & .10 & .45 & $12.86 * *$ & {$[.08-.12]$} \\
\hline Phobic anxiety & .06 & .34 & $9.25 * \star$ & {$[.05-.08]$} \\
\hline Paranoid ideation & .10 & .51 & $14.91 * *$ & {$[.09-.12]$} \\
\hline \multicolumn{5}{|c|}{ Step 3: Emotional dependence and psychopathological symptoms } \\
\hline Physical aggression received & .10 & .18 & $3.86^{* \star}$ & {$[.04-.17]$} \\
\hline Psychological violence received & .12 & .21 & $4.74^{\star \star}$ & {$[.07-.18$} \\
\hline Sexual coercion received & .06 & .18 & $3.98^{* \star}$ & {$[.03-.10]$} \\
\hline Injuries received & .05 & .20 & $4.33^{* *}$ & {$[.02-.08$} \\
\hline
\end{tabular}




\section{Discussion}

The first objective of the present study was to evaluate the relationships between emotional dependence, intimate partner violence, coping styles, early dysfunctional schemas and psychopathological symptomatology. The results showed that as emotional dependence and intimate partner violence increased, inadequate coping styles focused on emotion increased in parallel, reflecting the relevance of social withdrawal, self-criticism and wishful thinking. This difficulty in coping adequately presented by women who remain in violent relationships could be explained by beliefs originating in childhood related to being deserving of criticism as they feel incompetent and guilty for everything that happens around them. In addition, they believe that no one will pay attention to them, which can lead to a tendency to isolation (Navarro \& Albán, 2014), an absence of helpseeking, trust in others and expression of emotions (Loubat et al., 2007). For their part, people with emotional dependence also tend to voluntarily isolate themselves from their friends and family, although not as drastically with the latter in order to devote themselves completely to their partners (Castelló, 2005). Similarly, they tend to manifest negative thoughts about themselves that could explain the difficulty in setting limits in couple relationships, the need for the other to feel complete and the great difficulty in facing life on their own (Markez, 2015).

Similarly, an increase in emotional dependence and violence received was observed as early dysfunctional schemas increased, with the abandonment and subjugation schema predominating. In collation with this, previous studies have pointed out that suffering violence from representative figures in childhood would hinder the establishment of healthy partner relationships and increase the risk of remaining and choosing violent partners in adulthood (Herrenkohl \& Jung, 2016; Herrero, Torres, \& Rodriguez, 2018). Likewise, it has been shown how perceived parental care in childhood is a protective factor against remaining in violent intimate partner relationships (Kast, Eisenberg, \& Sieving, 2016). In this regard, regarding emotional dependence, early affective deficiencies have also been placed at the origin of this problem, which would generate dysfunctional schemes about oneself and others, as well as maladaptive interaction patterns (Castelló, 2005). Thus, it has been pointed out that people with emotional dependence develop abandonment schemas in childhood after experiencing intentional affective losses (Castelló, 2019). In addition, due to these established schemas they require constant confirmation that they are loved since they present beliefs of ineffectiveness and inability to be loved in a stable manner by other people that leads them to manifest a permanent fear of the possibility of abandonment or rejection (Pinzón \& Pérez, 2014).

Furthermore, correlation analysis revealed that greater emotional dependence and violence received were related to greater psychopathological symptomatology, being linked to a greater extent with depression, anxiety, interpersonal sensitivity, obsession-compulsion, and paranoid ideation. These results are in line with previous studies where depressive symptoms were associated with intimate partner violence victimization (Kong, Roh, Easton, Lee, \& Lawler, 2018). As for people with emotional dependence, they show comorbidity with mental disorders of the 
anxious-depressive spectrum (Castelló, 2005) and experience continuous emotional swings in their partner relationships that can be distressing and exhausting (Skvortsova \& Shumskiy, 2014). In addition, they may present pathological jealousy of the delusional type, which, despite not being based on an objective idea, they feel that they are absolutely certain of being deceived (Echeburúa \& Amor, 2016).

The second objective was to examine how negative coping styles mediated the association between emotional dependence and intimate partner violence. The results confirmed that the mechanism through which emotional dependence leads to staying in violent relationships was the use of maladaptive coping strategies, especially emotion-focused coping strategies, mediating the relationship between emotional dependence and injury to the greatest extent, followed by psychological, physical and sexual violence. This result is particularly relevant since the accumulated evidence suggests the existence of a close link between emotional dependence and intimate partner violence received (Momeñe \& Estévez, 2018), proving the mediating role exerted by the coping styles employed. These results could be due to the fact that experiences of abuse or neglect suffered by parents in childhood would predict a greater use of emotion-oriented coping strategies in adulthood (Pascuzzo, Cyr, \& Moss, 2013) and as previously mentioned, both permanence in violent intimate partner relationships and emotional dependence place their etiology in such negative experiences. In addition, these childhood experiences are a risk factor for the use of self-blaming coping strategies in the face of the abuse suffered. Victims would seek an explanation for the violent act suffered by a loved one, attributing it to their way of being, to their own person or to the fact that the behaviors they engage in are negative. This coping style of self-blame would last over time and would cause them to understand and justify the aggressions of others in the future (Polo et al., 2006). Another explanation for the results obtained could be related to alexithymia, since difficulties in identifying and expressing feelings generate an important obstacle for the resolution and coping of problems and have been considered a risk factor for suffering intimate partner violence (Moral de la Rubia \& Ramos-Basurto, 2015).

The third objective of the study was to analyze whether early dysfunctional schemas mediated the relationship between emotional dependence and intimate partner violence. The results obtained reflected the mediating role of early dysfunctional schemas, mediating to a greater extent the relationship between emotional dependence and sexual violence, followed by injuries, psychological and physical violence. Among the explanatory factors for the development of emotional dependence and early dysfunctional schemas is attachment theory. This theory postulates that negative experiences or unmet emotional needs lived in the first years of life with attachment figures would generate an inadequate attachment style that would influence the acquisition of dysfunctional schemas or beliefs about themselves and others and dependent personality traits (Izquierdo \& Gómez-Acosta, 2013; Valle \& Moral, 2018). In other words, the attachment styles established during childhood influence the choice of partner relationships and the behavior carried out in them and will also determine the beliefs or schemas they 
develop about themselves and others that will remain stable over time. Thus, the relationship with attachment figures during the first years of life constitutes the foundation on which the personality, the type of relationship with others and the beliefs or schemas will be built (Hernández, 2017; Young et al., 2013). For their part, it has been found that women who suffer intimate partner violence present dysfunctional beliefs or false myths about love generated by messages received since childhood (Marroquí, 2017) that would favor acceptance (Romero-Martínez, Lila, Gracia, Rodríguez, \& Moya-Albiol, 2019), justification and blaming women for gender violence (Ferrer-Pérez, Bosch-Fiol, Sánchez-Prada, \& Delgado-Álvarez, 2019).

Regarding the fourth objective, to analyze the mediating role of psychopathological symptoms in the relationship between emotional dependence and intimate partner violence. The data obtained confirm the mediating role of psychopathological symptoms, with a predominant relationship between emotional dependence and psychological and sexual violence, followed by injuries and physical violence. In this regard, previous studies have bidirectionally related depression and low levels of self-esteem to gender violence. That is, women who had been victims of violence were more likely to report greater depressive symptoms and low levels of self-esteem and in turn women with greater depressive symptoms and lower levels of self-esteem were more likely to suffer violence (Gonzalez-Guarda, De Santis, \& Vasquez, 2013). Another aspect to consider is that violence received and emotional dependence were positively related to self-criticism in the present study and the latter presented a strong association with depression (Petrocchi, Dentale, \& Gilbert, 2019), interpersonal problems and psychotic symptoms (Werner, Tibubos, Rohrmann, \& Reiss, 2019). In addition, childhood abuse and neglect, characteristic in people with emotional dependence and who remain in violent relationships, predict elevated levels of emotion dysregulation and symptoms of depression and anxiety in adulthood (Charak, Villarreal, Schmitz, Hirai, \& D Ford, 2019). As for people with emotional dependence, they tend to experience emotional oscillations and affective maladjustments in the form of negative feelings such as pain, sadness, despair, tiredness, constant fears, absence of freedom and distress in their relationships (Chui, Zilcha-Mano, Dinger, Barrett, \& Barber 2016; Skvortsova \& Shumskiy, 2014). Along these lines, the possible development of obsessive patterns of behavior has also been mentioned (Riso, 2014). In addition, it should be noted that emotionally dependent people tend to hide or misinterpret their dependence, emerging through symptom-satellites such as anxiety or depression (Sirvent \& Moral, 2018).

Some limitations should be addressed. First, the present study employs different sampling and assessment methodologies. However, previous studies have shown that there are no differences between the different sampling methods (Herrero-Fernández, 2015). Second, the sample consisted mostly of women who had attended or were attending university. Third, the cross-sectional nature of the study makes it impossible to obtain causal relationships. Also, people who present emotional dependence have difficulty accepting and recognizing the problem because many of the manifestations involved are socially accepted (Cogswell, Alloy, Karpinski, \& Grant, 2010). Similarly, evaluating past events can sometimes 
be complicated and may influence the results of the study (Balluerka, Lacasa, Gorostiaga, Muela, \& Pierrehumbert, 2011).

In conclusion, these findings are novel and valuable. Firstly, due to the absence of studies analyzing the coping styles used by emotionally dependent persons. Secondly, no studies have been found that evaluate the mediating role of coping styles, dysfunctional schemas and psychopathological symptoms in the relationship between emotional dependence and violence received. Finally, a clinical population has been included in the study. Therefore, the results obtained suggest the use of negative coping styles, dysfunctional schemas and psychopathological symptoms in women suffering from emotional dependence and intimate partner violence. In addition, emotional dependence has been linked to staying in violent relationships, but this association has been mediated by negative coping styles, dysfunctional schemas and psychopathological symptomatology. In terms of clinical implications, because coping styles, dysfunctional schemas and psychopathological symptoms can be modified, it is recommended to include them and take them into account as important objectives to work on and strengthen in treatment programs, since they have the potential to reduce the permanence in violent relationships in people with emotional dependence. In short, these results are very useful for identifying vulnerability factors in order to prevent their formation, facilitate their inclusion in treatment programs and evaluation protocols, and promote healthy couple relationships. It also allows the development of appropriate and effective therapeutic strategies once the relationship is established.

\section{References}

Alvarado, B. G., Sandín, B., Valdez-Medina, J. L., González-Arratia, N., \& Rivera, S. (2012). Análisis factorial confirmatorio del cuestionario SA-45 en una muestra mexicana [Confirmatory factor analysis of the SA-45 questionnaire in a Mexican sample]. Anales de Psicología, 28(2), 426-433. doi: 10.6018/analesps.28.2.148851

Balluerka, N., Lacasa, F., Gorostiaga, A. Muela, A., \& Pierrehumbert, B. (2011). Versión reducida del cuestionario CaMir (CaMir-R) para la evaluación del apego [Short version of CaMir questionnaire (CaMir-R) to assess attachment]. Psicothema, 23(3), 486-494.

Baron, R. M., \& Kenny, D. A. (1986). The moderator-mediator variable distinction in social psychological research: Conceptual, strategic and statistical considerations. Journal of Personality and Social Psychology, 51(6), 1173-1182.

Bornstein, R. F. (2012). Illuminating a neglected clinical issue: Societal costs of interpersonal dependency and dependent personality disorder. Journal of Clinical Psychology, 68(7), 766-781. doi: $10.1002 / j c l p .21870$

Calvete, E., Estévez, A., \& Corral, S. (2007). Trastorno por estrés postraumático y su relación con esquemas cognitivos disfuncionales en mujeres maltratadas [Posttraumatic Stress Disorder and its relationship with negative cognitive schemas in battered women]. Psicothema, 19(3), 446-451.

Calvete, E., Estévez, A., López de Arroyabe, E., \& Ruiz, P. (2005). The Schema Questionnaire Short Form. Structure and relationship with automatic thoughts and symptoms of affective disorders. European Journal of Psychological Assesment, 21(2), 90-99.

Castelló, J. (2005). Dependencia emocional: Características y tratamiento [Emotional dependence: Characteristics and treatment]. Madrid: Alianza. 
Castelló, J. (2012). La superación de la dependencia emocional [Overcoming emotional dependence]. Málaga: Corona Borealis.

Castelló, J. (2019). El miedo al rechazo en la dependencia emocional [Fear of rejection in emotional dependency]. Madrid: Alianza.

Charak, R., Villarreal, L., Schmitz, R. M., Hirai, M., \& D. Ford, J. (2019). Patterns of childhood maltreatment and intimate partner violence, emotion dysregulation, and mental health symptoms among lesbian, gay, and bisexual emerging adults: A threestep latent class approach. Child Abuse \& Neglect, 89, 99-110. doi: 10.1016/j.chiabu.2019.01.007

Chui, H., Zilcha-Mano, S., Dinger, U., Barrett, M. S., \& Barber, J. P. (2016). Dependency and self-criticism in treatments for depression. Journal of Counseling Psychology, 63(4), 452-459. doi: 10.1037/cou0000142

Cogswell, A., Alloy, L. B., Karpinski, A., \& Grant, D. A. (2010). Assessing dependency using self-report and indirect measures: Examining the significance of discrepancies. Journal of Personality Assessment, 92(4), 3016-316. doi: 10.1080/00223891.2010.481986

Coll-Vinent, B., Martí, G., Calderón, S., Martínez, B., Céspedes, F., \& Fuenzalida, C. (2019). La violencia de pareja en las pacientes que consultan por dolor torácico en urgencias [Domestic violence against women patients seen with chest pain in the emergency department]. Medicina de Familia, 45(1), 23-29.

Crane, C. A., \& Easton, C. J. (2017). Integrated treatment options for male perpetrators of intimate partner violence. Drug and Alcohol Review, 36(1), 24-33. doi: 10.1111/dar.12496

Crombie, N., Hooker, L., \& Reisenhofer, S. (2017). Nurse and midwifery education and intimate partner violence: A scoping review. Journal of Clinical Nursing, 26(15-16), 2100-2125. doi: 10.1111/jocn.13376

Davison, M. K., Bershadsky, B., Bieber, J., Silversmith, D., Maruish, M. E., \& Kane, R. L. (1997). Development of a brief, multidimensional, self-report instrument for treatment outcomes assessment in psychiatric settings: Preliminary findings. Assessment, 4, 259276. doi: 10.1177/107319119700400306

Del Castillo, A., Hernández, M. E., Romero, A., \& Iglesias, S. (2015). Violencia en el noviazgo y su relación con la dependencia emocional pasiva en estudiantes universitarios [Violence in the courtship and their relationship with the passive emotional dependence in university students]. Psicumex, 5(1), 4-18.

Echeburúa, E. (2018). Violencia y trastornos mentales: Una relación compleja [Violence and mental disorders: A complex relationship]. Madrid: Pirámide.

Echeburúa, E., \& Amor, P. J. (2019). Memoria traumática: estrategias de afrontamiento adaptativas e inadaptativas [Traumatic memory: adaptive and maladaptive coping strategies]. Terapia Psicológica, 37(1), 71-80. doi: 10.4067/S071848082019000100071

Echeburúa, E., \& Amor, P. J. (2016). Hombres violentos contra la pareja: ¿Tienen un trastorno mental y requieres tratamiento psicológico? [Male batterers: Are they mentally ill and are they needed of psychological treatment?]. Terapia Psicológica, 34(1), 31-40. doi: 10.4067/S0718-48082016000100004

Echeburúa, E., \& Fernández-Montalvo, J. (2010). Celos en la pareja: Una emoción destructiva [Jealousy in the couple: A destructive emotion]. Barcelona: Ariel.

Estévez, A. (2013). La infancia es para toda la vida [Childhood is for life]. In A. MartínezPampliega, \& L. Iriarte (Eds.), Avances en terapia de Pareja y Familia en contexto clínico y comunitario. Madrid: Editorial CCS.

Fernández-González, L., Calvete, E., \& Orue, I. (2017). Mujeres víctimas de violencia de género en centros de acogida características sociodemográficas y del maltrato [Women victims of gender violence in shelters: Sociodemographic and maltreatment characteristics]. Psychosocial Intervention, 26(1), 9-17. doi: 10.1016/j.psi.2016.10.001 
Ferrer-Pérez, V. A., Bosch-Fiol, E., Sánchez-Prada, A., \& Delgado-Álvarez, C. (2019). Beliefs and attitudes about intimate partner violence against women in Spain. Psicothema, 31(1), 38-45. doi: 10.7334/psicothema2018.206

Gonzalez-Guarda, R. M., De Santis, J. P., \& Vasquez, E. P. (2013). Sexual orientation and demographic, cultural and psychological factors associated with the perpetration and victimization of intimate partner violence among Hispanic men. Issues in Mental Health Nursing, 34(2), 103-109. doi: 10.3109/01612840.2012.728280

Graña, J. L., Andreu, J. M., Peña, M. E., \& Rodríguez-Biezma, M. J. (2013). Factor validity and reliability of the Revised Conflict Tactics Scales (CTS2) in a Spanish adult population. Behavioral Psychology/Psicología Conductual, 21(3), 525-543.

Hernández, M. (2017). Apego y psicopatología: La ansiedad y su origen. Conceptualización y tratamiento de las patologías relacionadas con la ansiedad desde una perspectiva integradora [Attachment and psychopathology: Anxiety and its origin. Conceptualization and treatment of anxiety-related pathologies from an integrative perspective]. Bilbao: Desclée De Brouwer.

Herrenkohl, T. I., \& Jung, H. (2016). Effects of child abuse, adolescent violence, peer approval and pro-violence attitudes on intimate partner violence in adulthood. Criminal Behaviour and Mental Health, 26(4), 304-314. doi: 10.1002/cbm.2014

Herrero, J., Torres, A., \& Rodríguez, F. J. (2018). Child abuse, risk in male partner selection, and intimate partner violence victimization of women of the European Union. Prevention Science, 19(8), 1102-1112. doi: 10.1007/s11121-018-0911-8

Herrero-Fernández, D. (2015). A comparison of Internet-based and paper-and-pencil questionnaires in assessing driving anger in a Spanish sample. REMA: Revista Electrónica de Metodología Aplicada, 20, 1-15.

Huerta, R., Ramírez, N., Ramos, J., Murillo, L., Falcón, C., Misare, M., \& Sánchez, J. (2016). Esquemas cognitivos disfuncionales y dependencia emocional en mujeres con y sin violencia en la relación de pareja de la ciudad de Lima [Early maladaptive schemas and emotional dependence in battered women and no battered women in the city of Lima]. Revista IIPSI, 19(2), 145-162. doi: 10.15381/rinvp.v19i2.12895

Iruarrizaga, I., Estévez, A., Momeñe, J., Olave, L., Fernández-Cárdaba, L., Chavez-Vera, M. D., \& Ferre-Navarrete, F. (2019). Dificultades en la regulación emocional, esquemas inadaptados tempranos y dependencia emocional en la adicción al sexo o comportamiento sexual compulsivo en la adolescencia [Difficulties in emotional regulation, early maladaptive schemas, and emotional dependence on sexual addiction or compulsive sexual behaviour in adolescence]. Revista Española de Drogodependencias, 44(1), 76-103.

Izquierdo, S. A., \& Gómez-Acosta, A. (2013). Dependencia afectiva: Abordaje desde una perspectiva contextual [Affective dependence: An approach of contextual perspective]. Psychologia: Avances de la Disciplina, 7(1), 81-91.

Jáuregui, P., Herrero-Fernández, D., \& Estévez, A. (2016). Estructura factorial del "Inventario de Estrategias de Afrontamiento" y su relación con la regulación emocional, ansiedad y depresión [Factorial structure of the Coping Strategies Inventory and its relationship with emotion regulation, anxiety and depression]. Behavioral Psychology/Psicología Conductual, 24(2), 319-340.

Kast, N. R., Eisenberg, M. E., \& Sieving, R.E. (2016). The role of parent communication and connectedness in dating violence victimization among Latino adolescents. Journal of Interpersonal Violence, 31(10), 1932-1955. doi: 10.1177/0886260515570750

Kong, J., Roh, S., Easton, S. D., Lee, Y. S., \& Lawler, M. J. (2018). A history of childhood maltreatment and intimate partner violence victimization among native American adults. Journal of Interpersonal Violence, 33(18), 2826-2848. doi: $10.1177 / 0886260516632353$ 
Lara, E. Z., Aranda, C., Zapata, R., Bretones, C., \& Alarcón, R. (2019). Depresión y ansiedad en mujeres víctimas de violencia en la relación de pareja [Depression and anxiety in women victims of intimate partner violence]. Revista Argentina de Ciencias del Comportamiento, 11(1), 1-8.

Lee, S., \& Lee, E. (2018). Predictors of intimate partner violence among pregnant women. International Journal of Gynaecology and Obstetrics, 140(2), 159-163. doi: 10.1002/ijgo. 12365

Lemos, M. y Londoño, N. H. (2006). Construcción y validación del cuestionario de dependencia emocional en población colombiana [Design and validation of the emotional dependence questionnaire in colombian population]. Acta Colombiana de Psicología, 9(2), 127-140.

Lemos, M., Jaller, C., González, A. M., Díaz, Z. T., \& De la Ossa, D. (2012). Perfil cognitivo de la dependencia emocional en estudiantes universitarios en Medellín, Colombia [Cognitive profile of emotional dependence in University Students from Medellín, Colombia]. Universitas Psychologica, 11(2), 395-404.

Llosa, S., \& Canetti, A. (2019). Depresión e ideación suicida en mujeres víctimas de violencia de pareja [Depression and suicide ideation in women victims of intimate partner violence]. Psicología, Conocimiento y Sociedad, 9(1), 1-27.

Loubat, M., Ponce, P., \& Salas, P. (2007). Estilo de apego en mujeres y su relación con el fenómeno del maltrato conyugal [Women's Attachment Style and Partner Abuse]. Terapia Psicológica, 25(2), 113-122.

Markez, I. (2015). Adicciones: Conocimiento, atención integrada y acción preventiva [Addictions: Knowledge, integrated care and preventive action]. Madrid: Asociación Española de Neuropsiquiatría.

Marroquí, M. (2017). Eso no es amor: 30 retos para trabajar la igualdad [That's not love: 30 challenges for equality work]. Barcelona: Planeta.

Miramontes, M. M., \& Mañas, I. (2018). Vinculación afectiva al agresor en la mujer joven víctima de violencia de género tras la separación [Emotional attachment in younger female victims of domestic violence to their abuser after separation]. Revista de Psicología, 27(1), 1-12. doi: 10.5354/0719-0581.2018.50741

Mohammad-Alizadeh-Charandabi, S., Bahrami-Vazir, E., Kamalifard, M., \& Mirghafourvand, M. (2016). Intimate partner violence during the first pregnancy: A comparison between adolescents and adults in an urban area of Iran. Journal of Forensic and Legal Medicine, 43, 53-60. doi: 10.1016/j.jflm.2016.07.002

Momeñe, J., \& Estévez, A. (2018). Los estilos de crianza parentales como predictores del apego adulto, de la dependencia emocional y del abuso psicológico en las relaciones de pareja adultas [Parental parenting styles as predictors of adult attachment, emotional dependence, and psychological abuse in adult couple relationships]. Behavioral Psychology/Psicología Conductual, 26(2), 359-377.

Momeñe, J., \& Estévez, A. (2019). El papel de la resiliencia en la dependencia emocional y el abuso psicológico [The role of resilience in emotional dependence and psychological abuse]. Revista Española de Drogodependencias, 44(1), 28-43.

Moral, M. V., García, A., Cuetos, G., \& Sirvent, C. (2017). Violencia en el noviazgo, dependencia emocional y autoestima en adolescentes y jóvenes españoles [Dating violence, emotional dependence and self-esteem in Spanish adolescents and young adults]. Revista Iberoamericana de Psicología y Salud, 8(2), 96-107. doi: 10.23923/j.rips.2017.08.009

Moral, M. V., Sirvent, C., Ovejero, A., \& Cuetos, G. (2018). Dependencia emocional en las relaciones de pareja como síndrome de Artemisa: Modelo explicativo [Emotional dependence on relationships and Artemis syndrome: Explanatory model]. Terapia Psicológica, 36(3), 156-166. doi: 10.4067/S0718-48082018000300156 
Moral de la Rubia, J., \& Ramos-Basurto, S. (2015). Alexitimia como predictor directo y mediado por la depresión en la violencia de pareja [Alexitimia as a direct and depression-mediated predictor of couple violence]. Revista Costarricense de Psicología, 34(1), 15-40.

Moral de la Rubia, J., López, F., Díaz, R., \& Cienfuegos, Y. I. (2011). Diferencias de género en afrontamiento y violencia en la pareja [Gender differences in coping and violence in couple relationships]. CES Psicología, 4(2), 29-46.

Navarro, E. A. C., \& Albán, R. L. C. (2014). Relación entre "mujer víctima de violencia doméstica" y "síndrome de mujer maltratada" en Trujillo, Perú [Relationship between "woman victim of domestic violence" and "battered women's syndrome" in Trujillo, Peru]. Revista Ciencia y Tecnología, 10(3), 159-169.

Oliva, A. (2011). Apego en la adolescencia [Attachment during adolescence]. Acción Psicológica, 8(2), 55-65.

Pascuzzo, K., Cyr, C., \& Moss, E. (2013). Longitudinal association between adolescent attachment, adult romantic attachment, and emotion regulation strategies. Attachment \& Human Development, 15(1), 83-103. doi: 10.1080/14616734.2013.745713

Petrocchi, N., Dentale, F., \& Gilbert, P. (2019). Self-reassurance, not self-esteem, serves as a buffer between self-criticism and depressive symptoms. Psychology and Psychotherapy, 92(3), 394-406. doi: 10.1111/papt.12186

Petruccelli, F., Diotaiuti, P., Verrastro, V., Petruccelli, I., Federico, R., Martinotti, G., Fossati, A., Di Giannantonio, M., \& Janiri, L. (2014). Affective dependence and aggression: An exploratory study. BioMed Research International. https://www.ncbi.nlm.nih.gov/pubmed/25054147

Pinzón, B. K., \& Pérez, M. A. (2014). Estilos de apego: Mujeres que sufren violencia conyugal [Attachment styles: Women suffering from marital violence]. Psicología $y$ Salud, 24(1), 65-75.

Polo, C., López, M., Olivares, D., Escudero, A., Rodríguez, B., \& Fernández, A. (2006). Selfblame in women battered by their partners. Implied factors. Revista de la Asociación Española de Neuropsiquiatría, 26(97), 71-86.

Riso, W. (2014). ¿Amar o depender? Cómo superar el apego afectivo y hacer del amor una experiencia plena y saludable [To love or to depend? How to overcome affective attachment and make love a full and healthy experience]. Barcelona: Planeta.

Romero-Martínez, A., Lila, M., Gracia, E., Rodríguez, C. M., \& Moya-Albiol, L. (2019). Acceptability of intimate partner violence among male offenders: The role of setshifting and emotion decoding dysfunctions as cognitive risk factors. International Journal of Environmental Research and Public Health, 16(9), 1537. doi: 10.3390/ijerph16091537

Ruiz-Pérez, I., Pastor-Moreno, G., Escribà-Agüir, V., \& Maroto-Navarro, G. (2018). Intimate partner violence in women with disabilities: Perception of healthcare and attitudes of health professionals. Disability and Rehabilitation, 40(9), 1059-1065. doi: 10.1080/09638288.2017.1288273

Sandín, B., Valiente, R. M., Chorot, P., Santed, M. A., \& Lostao, L. (2008). SA-45: Forma abreviada del SCL-90 [SA-45: A brief form of the SCL-90]. Psicothema, 20(2), 290296.

Santamaría, J. J., Merino, L., Montero, E., Cano, M., Fernández, T., Cubero, P., LópezFernández, O., \& González-Bueso, V. (2015). Perfil psicopatológico de pacientes con dependencia emocional [Psychopatological profile of affective dependence patients]. Cuadernos de Medicina Psicosomática y Psiquiatría de Enlace, 116, 36-46.

Sirvent, C., \& Moral, M. V. (2018). Construcción y validación del Inventario de relaciones interpersonales y dependencias sentimentales (IRIDS-100) [Construction and validation 
of the Inventory Sentimental Relationships and Dependences (IRIDS-100)]. Health and Addictions, 18(2), 35-47.

Skvortsova, S. N., \& Shumskiy, V. B. (2014). Existential-phenomenological analysis of dependence in close interpersonal relationships. Existenzanalyse, 31(1), 4-13.

Sloand, E., Killion, C., Yarandi, H., Sharps, P., Lewis-O'Connor, A., Hassan, M., Gary, F., Cesar, N. M., \& Campbell, D. (2017). Experiences of violence and abuse among internally displaced adolescent girls following a natural disaster. Journal of Advanced Nursing, 73(12), 3200-3208. doi: 10.1111/jan.13316

Straus, M. A., Hamby, S. L., Buncy-McCoy, S., \& Sugarman, D. B. (1996). The revised Conflict Tactics Scales (CTS2): Development and preliminary psychometric data. Journal of Family Issues, 17(3), 283-316. doi: 10.1177/019251396017003001

Tobin, D. L., Holroyd, K. A., Reynolds, R. V., \& Wigal, J. K. (1989). The hierarchical factor structure of the coping strategies inventory. Cognitive Therapy and Research, 13(4), 343-361.

Urbiola, I., \& Estévez, A. (2015). Dependencia emocional y esquemas desadaptativos tempranos en el noviazgo de adolescentes y jóvenes [Emotional dependence and early maladaptive schemas in adolescent and young adult courtship]. Behavioral Psychology/Psicología Conductual, 23(3), 571-587.

Urbiola, I., Estévez, A. e Iraurgi, I. (2014). Dependencia emocional en el noviazgo en jóvenes y adolescentes (DEN): Desarrollo y validación de un instrumento [Emotional dependence in dating in youth and adolescents (DEN): Development and validation of an instrument]. Ansiedad y Estrés, 20(2-3), 101-114.

Urbiola, I., Estévez, A., Iruarrizaga, I., \& Jauregui, P. (2017). Dependencia emocional en jóvenes: Relación con la sintomatología ansiosa y depresiva, autoestima y diferencias de género [Emotional dependence in young people: Relationship with anxious and depressive symptomatology, self-esteem and gender differences]. Ansiedad y Estrés, 23(1), 6-11. doi: 10.1016/j.anyes.2016.11.003

Urbiola, I., Estévez, A., Iruarrizaga, I., Momeñe, J., Jáuregui, P., Bilbao, M., \& Orbegozo, U. (2019). Dependencia emocional en el noviazgo: Papel mediador entre la autoestima y la violencia psicológica en jóvenes [Emotional dependence in courtship: The mediating role between self-esteem and psychological violence in young people]. Revista Española de Drogodependencias, 1(44), 13-27.

Valle, L., \& Moral, M. V. (2018). Dependencia emocional y estilo de apego adulto en las relaciones de noviazgo en jóvenes españoles [Emotional dependence and adult attachment style in dating relationships in Spanish young people]. Revista Iberoamericana de Psicología y Salud, 9(1), 27-41.

Van Ouytsel, J., Ponnet, K., \& Walrave, M. (2017). The associations of adolescents' dating violence victimization, well-being and engagement in risk behaviors. Journal of Adolescence, 55, 66-71. doi: 10.1016/j.adolescence.2016.12.005

Werner, A. M., Tibubos, A. N., Rohrmann, S., \& Reiss, N. (2019). The clinical trait selfcriticism and its relation to psychopathology: A systematic review - update. Journal of Affective Disorders, 246, 530-547. doi: 10.1016/j.jad.2018.12.069

Young, J. E., \& Brown, G. (1994). Young Schema Questionnaire (2nd ed.). In J. E. Young (Ed.), Cognitive therapy for personality disorders: A schema-focused approach (Rev. Ed.). Sarasota, FL.: Professional Resource Exchange.

Young, J. E., Klosko, J. S., \& Weishaar, M. E. (2013). Terapia de esquemas: Guía práctica [Schema therapy: A practical guide]. Bilbao: Desclée de Brouwer.

RECEIVED: April 16, 2020

ACCEPTED: September 1, 2020 